\title{
Persepsi Mahasiswi Tentang Kanker Payudara dan Perilakunya terhadap Pencegahan Kanker Payudara di Fakultas Keperawatan Universitas Andalas
}

\author{
Ria Delviani.R.S ${ }^{\mathrm{a}}$, Vetty Priscilla ${ }^{\mathrm{a}}$ \\ ${ }^{a}$ Fakultas Keperawatan Universitas Andalas
}

\begin{abstract}
The incidence of the breast cancer has increasing dramatically every year, approximately 68,6\% women with breast cancer go to get treatment at the advanced stage, so they get difficult to be cured, while the breast cancer could be detected at the beginning stage through breast self-examination or BSE. BSE is is the most effective way for early prevention of breast cancer. The perceptions about breast cancer will affect one's BSE behavior. The purpose of this study was to know the perception of breast cancer susceptibility and severity, also the perception of the benefits and barriers of student BSE and found out the relation between the perceptions with BSE behavior. This study was analytical used cross sectional design, it was done from January up to June 2013. The sample of this study included 76 students of nursing and they were taken by using stratified random sampling. Using univariate analysis, and bivariate (with Chi Square Test). The result of the study indicated that about 59,2 \% respondents had BSE behavior is not well, 52,6\% respondents have perceptions of positive susceptibility, 52,6\% respondents have perceptions of negative severity. 59,2\% respondents have perceptions of benefits negatif and 52,6\% respondents have perceptions of barrier negative. There is a relation between the perceptions susceptibility, severity, benefits, barrier with BSE behavior. Necessary to increasse the role of educators in providing information about breast cancer and its early detection, to be improving student knowledge and skills in the application.
\end{abstract}

Key words: breast cancer, perception of health belief model, breast self-examination (BSE)

\begin{abstract}
Abstrak: Kanker payudara memiliki angka kejadian yang terus meningkat setiap tahunnya, dan 68,6\% wanita dengan kanker payudara berobat pada stadium lanjut sehingga sulit untuk disembuhkan, padahal kanker payudara dapat dideteksi pada stadium awal dengan pemeriksaan payudara sendiri (SADARI). SADARI merupakan cara yang paling efektif untuk pencegahan dini kanker payudara. Persepsi mengenai kanker payudara akan mempengaruhi perilaku SADARI seseorang. Tujuan penelitian ini adalah untuk mengetahui persepsi kerentanan dan keparahan kanker payudara, serta persepsi manfaat dan hambatan SADARI mahasiswi dan mencari hubungan antara persepsi tersebut dengan perilaku SADARI. Penelitian ini bersifat analitik, menggunakan desain cross sectional study, dilaksanakan dari Januari sampai Juni 2013. Sampel pada penelitian ini sebanyak 76 mahasiswi keperawatan, diambil dengan teknik stratified random sampling. Menggunakan analisis univariat, bivariat (dengan uji Chi Square). Hasil penelitian ini menunjukkan bahwa 59,2\% responden memiliki perilaku SADARI tidak baik, 52,6\% persepsi kerentanan positif, 52,6\% persepsi keparahan negatif, 59,2\% Persepsi manfaat negatif dan 52,6\% persepsi hambatan negatif. Terdapat hubungan antara persepsi kerentanan, keparahan, manfaat dan hambatan terhadap perilaku SADARI. Diperlukan peningkatkan peran pendidik dalam menyampaikan informasi tentang kanker payudara dan SADARI,agar dapat meningkatkan pengetahuan dan keterampilan mahasiswi dalam aplikasinya.
\end{abstract}

Kata kunci: $\quad$ Kanker payudara, persepsi model kepercayaan kesehatan, Pemeriksaan Payudara $\quad$ Sendiri (SADARI).

Kanker adalah suatu keganasan yang terjadi karena adanya sel dalam tubuh yang berkembang secara tidak terkendali sehingga pertumbuhannya menyebabkan kerusakan bentuk dan fungsi dari organ tempat sel tersebut tumbuh (Sjamsuhidajat dan De Jong, 2004). Kanker merupakan momok yang menakutkan bagi masyarakat karena selalu diidentikkan dengan kematian. Ada beberapa kanker yang masih tinggi kejadiannya di dunia, seperti kanker kolon, kanker leher 
rahim, kanker payudara, kanker prostat dan kanker nasofaring yang belum dikenal cara pencegahannya. Berdasarkan penelitian yang dilakukan oleh Breast Health global initiative, sekarang ini kanker payudara merupakan kanker dengan prevalensi tertinggi di dunia (UICC, 2010).

Kanker payudara adalah sekelompok sel yang tidak normal pada payudara yang terus tumbuh berlipat ganda. Dalam tubuh terdapat berjuta-juta sel, salah satunya adalah sel abnormal atau sel metaplasia, yaitu sel yang dapat berubah-ubah tetapi masih dalam batas normal. Akan tetapi, jika sel metaplasia ini dipengaruhi oleh faktor lain maka akan menjadi sel displasia. Kanker ini adalah yang paling umum diderita wanita, hampir sepertiga kanker yang didiagnosa pada wanita adalah kanker payudara (Amelia, 2009).

Kanker payudara masih menjadi masalah besar di Indonesia, karena 68,6\% wanita dengan kanker payudara berobat ke dokter pada stadium lanjut lokal (IIIa dan IIIb), sedangkan stadium dini (stadium I dan II) hanya 22, 4\%. Padahal kanker payudara seperti kanker pada umumnya dimana kesuksesan pengobatannya sangat ditentukan oleh deteksi pada stadium awal. (Depkes, 2008).

Sumatera Barat memiliki angka kejadian kanker $(5,6 \%)$ lebih tinggi dari rata-rata nasional $(4,3 \%)$, yaitu pada urutan tertinggi ke-enam dari 33 provinsi di Indonesia berdasarkan Riskesdas Nasional tahun 2008 dan data dari RSUP dr. M.Djamil Padang tahun 2010, kanker payudara adalah jenis yang tertinggi dari seluruh kejadian kanker. Pada tahun 2012, di Instalasi Rawat Jalan RSUP dr.M.Djamil kasus kanker payudara berjumlah 204 kasus, sedangkan di Instalasi Rawat Inap berjumlah 272 kasus. Di Instalasi Rawat Inap tersebut terdapat $8,5 \%$ penderita (23 orang) berusia 35 tahun ke bawah, usia termuda adalah 22 tahun. Bahkan, di Instalasi Rawat Jalan usia termuda penderita adalah 14 tahun. Sebagian besar Penderita kanker payudara di
RSUP dr.M.Djamil (54\%) berasal dari Kota Padang.

Menurut badan kesehatan dunia (World health organization), satu-satunya cara yang efektif sampai saat ini hanya dengan melakukan deteksi sedini mungkin pada kemungkinan timbulnya penyakit ini, yaitu dengan melakukan Pemeriksaan Payudara Sendiri (SADARI) (Fadillah, 2009). Pada usia 20 tahun seorang wanita dianjurkan untuk melakukan pemeriksaan pada payudaranya sendiri setiap bulan atau setiap tiga bulan sekali untuk dapat mendeteksi secara dini jika terdapat kelainan dan segera mendapatkan penanganan yang tepat (Setiati, 2009).

Pemeriksaan payudara sendiri merupakan pemeriksaan / perabaan sendiri untuk menemukan timbulnya benjolan abnormal pada payudara (Otto, S, 2005). SADARI sangat penting dilakukan karena setiap wanita normal dan memiliki siklus haid normal merupakan population at risk dari kanker payudara dan keunggulan SADARI adalah dapat menemukan tumor atau benjolan payudara pada stadium awal, penemuan awal benjolan dipakai sebagai rujukan melakukan mammography untuk mendeteksi interval kanker, mendeteksi benjolan yang tidak terlihat saat melakukan mammografi dan menurunkan angka kematian akibat kanker payudara (Keraney \& Murray, 2006).

Masalah dalam penanggulangan kanker payudara di Indonesia adalah walaupun ada peningkatan kewaspadaan terhadap kanker payudara, masih banyak wanita yang belum menyadari pentingnya melakukan deteksi dini. Menurut Survei Yayasan Kesehatan Payudara Jakarta tahun 2005, sebanyak 80\% masyarakat tidak mengerti akan pentingnya melakukan pemeriksaan dini payudara, hanya $11,5 \%$ yang paham, sementara sisanya tidak tahu $(8,5 \%)$. Padahal di negara lain, program-program deteksi dini kanker payudara telah banyak dikembangkan (Agnes, 2010). Ini menyebabkan penderita datang ke pelayanan kesehatan sudah dalam stadium lanjut. 
Tjindarbumi melaporkan penderita yang berobat pada stadium dini hanya berkisar 20$30 \%$. Sedangkan penderita yang datang pada stadium lanjut sebanyak $70 \%$ di RS Kanker Dharmais, dan 68,6 \% di RSUP dr.M.Djamil Padang. Kondisi ini jauh berbeda dengan negara barat yang hampir $80 \%$ pasien kanker payudara datang pada stadium dini (Azamris, 2006).

Menurut Bustan (2007), rendahnya kesadaran untuk memeriksakan diri ini tidak hanya terjadi pada wanita dengan pendidikan atau ekonomi rendah, tetapi juga mereka yang berpendidikan tinggi atau cukup mapan, bahkan di kalangan profesi kedokteran sendiri. Ini menunjukkan bahwa perilaku kesehatan itu sendiri dipengaruhi oleh karakteristik individu, penilaian individu terhadap perubahan yang di tawarkan atau dengan kata lain di sebut persepsi.

Mahasiswi yang menempuh pendidikan dibidang kesehatan pada umumnya telah memperoleh informasi tentang SADARI sehingga mereka cenderung mempunyai pengetahuan SADARI yang baik. Kerangka model perilaku Health belief model memberikan penjelasan mengapa seorang individu melakukan dan tidak melakukan perilaku sehat. Menurut teori health belief model, tindakan individu dalam upaya mencegah penyakit, dipengaruhi oleh enam komponen atau variabel kunci yang terlibat didalam tindakan tersebut, dalam variabel tersebut terdapat empat persepsi yang dianggap mempengaruhi yaitu perceived susceptibility (persepsi kerentanan), perceived severity (persepsi keparahan), perceived benefits (persepsi manfaat), perceived barriers (persepsi hambatan) (Notoatmodjo,2003)

Berdasarkan hasil penelitian Desanti (2008), pada wanita yang beresiko kanker

\section{METODE}

Penelitian ini bersifat analitik yang bertujuan untuk mengetahui hubungan antara persepsi dan perilaku pemeriksaan payudara payudara di Semarang, Jawa Tengah, menyatakan bahwa perceived susceptibility dan severity tidak berhubungan dengan perilaku SADARI, variabel perceived barriers dan perceived benefits berhubungan dengan perilaku SADARI. (Junita,2004). Namun hasil penelitian Lashey dan Wyper tentang breast self examination behaviour (tindakan SADARI) menyatakan bahwa Perceived Susceptibility adalah predictor terbaik dari tindakan SADARI.

Mahasiswi Fakultas Keperawatan Universitas Andalas adalah institusi kesehatan yang mencetak tenaga kesehatan yang terutama bergerak di bidang kesehatan promotif dan preventif. Oleh karena itu, diharapkan mahasiswi Fakultas Keperawatan Unand dapat berperan serta sebagai role model di masyarakat dan menjadi faktor pengubah perilaku masyarakat kearah yang lebih baik. Di tambah lagi, para mahasiswi sendiri berada pada kelompok usia yang direkomendasikan untuk melaksanakan SADARI, maka sudah selayaknya mahasiswi memiliki perilaku SADARI yang baik.

Berdasarkan studi pendahuluan terhadap 30 mahasiswi Fakultas Keperawatan Unand, diketahui bahwa umumnya mahasiswi telah mendapatkan perkuliahan tentang kanker payudara dan mengetahui tentang SADARI, dan hanya $34 \%$ (10 orang) yang melakukan SADARI dan $64 \%$ (20 orang) lainnya tidak melakukan tindakan SADARI dikarenakan malas, malu dan risih untuk melakukan SADARI. Tujuan dari penelitian ini untuk mengetahui persepsi mahasiswi tentang kanker payudara dan perilakunya dalam melakukan pemeriksaan payudara sendiri (SADARI) di Fakultas Keperawatan Unand.

sendiri pada mahasiswi fakultas keperawatan Universitas Andalas dengan menggunakan desain cross sectional yaitu jenis penelitian yang menekankan pada waktu 
pengukuran/observasi data variabel independen dan dependen hanya satu kali, pada satu saat, dilakukan dalam waktu yang bersamaan (Nursalam, 2003).

Populasi dalam penelitian ini adalah mahasiswi fakultas Keperawatan Universitas Andalas angkatan 2009,2010, dan 2011 dengan jumlah sampel yaitu 76 orang. Teknik pengampilan sampel yang digunakan adalah stratified random sampling yaitu populasi dibedakan menjadi beberapa strata berdasarkan angkatan mahasiswi. Penelitian di lakukan dari tanggal 6 sampai 18 Mei 2013 di Fakultass Keperawatan Universitas Andalas

\section{HASIL DAN PEMBAHASAN}

Hasil penelitian ini disajikan dalam dua bagian umum yaitu univariat dan bivariat.

Tabel I. Karakteristik Umum Responden Berdasarkan Usia

\begin{tabular}{|l|l|c|c|}
\hline No. & $\begin{array}{l}\text { Karakteristik } \\
\text { Responden }\end{array}$ & f & \% \\
\hline 1. & Usia & & \\
& 20 Tahun & 35 orang & 46,1 \\
& 21 Tahun & 30 orang & 39,5 \\
& 22 Tahun & 11 orang & 14,5 \\
\hline & Total & $\mathbf{7 6}$ orang & $\mathbf{1 0 0}$ \\
\hline
\end{tabular}

Tabel 2.

Distribusi Frekuensi Persepsi kerentanan, Keparahan, Manfaat, Hambatan dan Perilaku SADARI di Fakultas Keperawatan Universitas Andalas Padang Tahun 2013

\begin{tabular}{|c|l|l|c|c|}
\hline No & Variabel & Kategori & Frekuensi & \% \\
\hline 1 & Persepsi & Positif & 40 orang & 52,6 \\
& kerentanan & Negatif & 36 orang & 47,4 \\
& & & & \\
\hline 2 & Persepsi & Positif & 36 orang & 47,4 \\
& Keparahan & Negatif & 40 orang & 52,6 \\
\hline 3 & Persepsi & Positif & 31 orang & 40,8 \\
& Manfaat & Negatif & 45 orang & 59,2 \\
\hline
\end{tabular}

Padang. Cara pengumpulan data yang digunakan dalam penelitian ini adalah dengan memberikan kuesioner kepada mahasiswi yang telah ditetapkan menjadi responden penelitian.

Analisa data yang disajikan adalah gambaran distribusi frekuensi setiap variabel penelitian,melalui analisis ini dapat digambarkan karakteristik dari variabel penelitian. Data diolah secara komputerisasi untuk mengetahui hubungan antara variabel dependen dengan variabel independen dengan menggunakan uji Chi-Square dengan interprestasi kemaknaan $\mathrm{p}<0,05$.

\begin{tabular}{|c|l|l|c|c|}
\hline 4 & Persepsi & Positif & 36 orang & 47,4 \\
& Hambatan & Negatif & 40 orang & 52,6 \\
\hline 5 & Perilaku & Baik & 31 orang & 40,8 \\
& SADARI & $\begin{array}{l}\text { Tidak } \\
\text { baik }\end{array}$ & 45 orang & 59,2 \\
& & & \\
\hline
\end{tabular}

Hasil penelitian ini menunjukkan bahwa dari 76 mahasiswi, terdapat 40 orang $(52,6 \%)$ mahasiswi yang memiliki persepsi positif mengenai kerentanan terhadap kanker payudara. Dibandingkan dengan mahasiswi yang memiliki persepsi negative, hanya $47,4 \%$. Ini menunjukkan bahwa proporsi mahasiswi dengan persepsi yang positif lebih banyak dibandingkan mahasiswi dengan persepsi yang negative, menurut Walgito, proses terjadinya persepsi tergantung dari pengalaman masa lalu dan pendidikan yang diperoleh individu. Oleh karena itu sudah sepatutnya mahasiswi keperawatan yang merupakan sample dalam penelitian ini memiliki persepsi yang positif mengenai kerentanan terhadap kanker payudara, karena responden telah mendapatkan pembelajaran mengenai kanker payudara dan SADARI di bangku perkuliahan.

Hasil penelitian menunjukkan bahwa proporsi terbesar adalah proporsi persepsi negative mengenai keparahan kanker payudara, yaitu 52,6\%. Dibandingkan dengan angka responden yang memiliki persepsi positif mengenai keparahan kanker payudara 
yaitu 47,4\%. Rosentock (1982) dalam Notoatmodjo 2007, mengatakan bahwa persepsi keparahan mengacu pada keyakinan seseorang mengenai efek suatu penyakit tertentu. Efek ini dapat dirasakan dari sudut pandang kesulitan-kesulitan yang menciptakan timbulnya suatu penyakit. Dari hasil analisa kuesioner didapatkan, bahwa masih banyak responden yang memiliki persepsi yang salah mengenai ancaman kanker payudara, antara lain mereka menganggap bahwa kanker payudara dapat diobati dan tidak mempengaruhi umur seseorang, padahal data (Depkes, 2007) menunjukkan bahwa angka kematian kanker payudara mencapai 410.000setiap tahunnya. Selain itu responden menganggap bahwa benjolan pada payudara merupakan hal yang biasa dan tidak perlu dikhawatirkan.

Sebagian besar responden memiliki persepsi yang negatif mengenai manfaat SADARI, hanya sebagian kecil yaitu 40,8\% yang memiliki persepsi positif mengenai manfaat SADARI. Padahal menurut Suryaningsih (2009) SADARI memiliki manfaat untuk mendeteksi kanker payudara sejak dini oleh wanita usia subur yang disarankan melakukannya, dan responden merupakan mahasiswi keperawatan yang telah mempelajari mengenai hal itu.

Hasil penelitian ini menunjukkan masih cukup banyak mahasiswi fakultas keperawatan yang tidak memahami pentingnya melakukan SADARI, padahal Foster dan Constanta menemukan bahwa kematian oleh kanker payudara lebih sedikit pada perempuan yang melakukan pemeriksaan dibandingkan yang tidak.

Proporsi responden yang memiliki persepsi negative mengenai hambatan yang dirasakan untuk melakukan SADARI lebih besar dibandingkan persepsi positif. Stephenson (2004) dalam Purwaningsih (2009), mengatakan bahwa salah satu alasan utama individu tidak mengubah perilaku kesehatan mereka karena mereka berpikir melakukan hal tersebut akan menimbulkan kesulitan, baik kesulitan secara psikologis atau fisik maupun sosial.

Banyaknya mahasiswi yang memiliki perilaku SADARI tidak baik ini berasal dari mahasiswi angkatan 2009 yang telah masuk klinik, dan merawat pasien dengan kanker payudara, hal ini dapat terjadi karena mereka mendapatkan pengetahuan tentang kanker payudara dan SADARI di semester II sementara sehingga untuk praktek dalam kehidupan sehari-harinya sangat tergantung pada ingatan seseorang, sesuai dengan Notoatmodjo 2007 yang mengemukakan bahwa penegtahuan terjadi setelah orang melakukan penginderaan terhadap objek tertentu, Penginderaan yang baik akan menghasilkan pemahaman yang baik terhadap suatu objek atau informasi, maka jika seorang mahasiswi mendapatkan perkuliahan mengenai kanker payudara dan SADARI namun tidak melakukan penginderaan yang baik, pemahaman yang munculpun kurang baik. Selain itu, menurut Notoatmodjo 2007, kemampuan mengingat seseorang dipengaruhi oleh dimensi waktu. 
Tabel 3. Hubungan Persepsi kerentanan, keparahan, manfaat dan hambatan terhadap perilaku SADARI

\begin{tabular}{|c|c|c|c|c|c|c|c|c|c|}
\hline \multirow{3}{*}{ No } & \multirow{3}{*}{ Persepsi } & \multirow{3}{*}{ Kategori } & \multicolumn{4}{|c|}{ Perilaku SADARI } & \multirow{2}{*}{\multicolumn{2}{|c|}{ Total }} & \multirow{3}{*}{$p$} \\
\hline & & & \multicolumn{2}{|c|}{ Baik } & \multicolumn{2}{|c|}{ Tidak Baik } & & & \\
\hline & & & f & $\%$ & f & $\%$ & f & $\%$ & \\
\hline \multirow{2}{*}{1} & \multirow{2}{*}{ kerentanan } & Positif & 23 & 57,5 & 17 & 42,5 & 40 & 100 & \multirow{2}{*}{0,004} \\
\hline & & Negatif & 8 & 22,2 & 28 & 77,8 & 36 & 100 & \\
\hline \multirow{2}{*}{2} & \multirow{2}{*}{ Keparahan } & Positif & 20 & 80 & 5 & 20 & 25 & 100 & \multirow{2}{*}{0,007} \\
\hline & & Negatif & 10 & 25,0 & 30 & 75,0 & 40 & 100 & \\
\hline \multirow{2}{*}{3} & \multirow{2}{*}{ manfaat } & Positif & 22 & 71,0 & 9 & 29,0 & 31 & 100 & \multirow{2}{*}{0,000} \\
\hline & & Negatif & 9 & 20,0 & 36 & 80,0 & 45 & 100 & \\
\hline \multirow{2}{*}{4} & \multirow{2}{*}{ Hambatan } & Positif & 20 & 55,6 & 16 & 44,4 & 36 & 100 & \multirow{2}{*}{0,024} \\
\hline & & Negatif & 11 & 27,5 & 29 & 72,5 & 40 & 100 & \\
\hline
\end{tabular}

Hasil penelitian menunjukkan bahwa semua nilai $\mathrm{p}$ value kecil dari 0,05 yaitu terdapat $\mathrm{p}$ value 0,004 pada persepsi keretanan, 0,007 pada persepsi keparahan, 0,000 pada persepsi manfaat, dan 0,024 pada persepsi hambatan terhadap perilaku SADARI. Hasil penelitian ini menunjukkan bahwa terdapat diantara mereka yaitu $(42,5 \%)$ responden yang memiliki persepsi positif bahwa dirinya rentan untuk terkena kanker payudara, namun perilaku SADARInya masih tidak baik. Menurut analisa kuesioner menunjukkan responden tersebut masih belum rutin melakukan SADARI dan langkah yang dilakukan masih belum tepat. Hasil penelitian ini sesuai dengan penelitian Lashey dan Wyper tentang breast self examination behaviour (tindakan SADARI) yang menyatakan bahwa persepsi kerentanan adalah predictor terbaik dari tindakan SADARI. Namun menurut hasil penelitian Desanti 2008 dalam penelitiannya terhadap wanita yang beresiko kanker payudara di Semarang, Jawa tengah, bahwa variabel persepsi kerentanan tidak berhubungan dengan perilaku SADARI (Junita,2004), dalam penelitian ini hanya $25,5 \%$ responden yang mempunyai persepsi positif tentang kerentanan menderita kanker payudara dan dalam hasil penelitiannya Desanti menjelaskan bahwa masih cukup banyak responden yang memiliki persepsi salah mengenai factor resiko kanker payudara.

Persepsi keseriusan yang dirasakan terhadap kanker payudara kemungkinan juga berbeda-beda pada setiap individu. Hal itu karena tiap orang memiliki pandangan yang subjektif terhadap keseriusan kanker payudara walaupun mereka mendaapatkan materi kuliah yang sama tentang kanker payudara. Salah satu variabel yang mungkin dapat mempengaruhi dalam merasakan keseriusan kanker payudara sehingga mendorong dirinya untuk melakukan SADARI adalah faktor lingkungan mungkin dapat menjadi salah satu faktor pendorong yang membuat responden merasakan keseriusan yang kuat terhadap kanker payudara, sehingga dapat memotivasi dirinya untuk melakukan SADARI dengan baik. Menurut Fisbhein (2000) dalam Ekasari (2010), kondisi lingkungan merupakan salah satu faktor yang dapat mempengaruhi perilaku manusia secara langsung.

Dari hasil penelitian didapatkan pula responden dengan persepsi yang positif namun perilaku SADARI nya belum baik, hasil analisa kuesioner menunjukkan bahwa responden massih belum melakukan dengan 
teratur, dan prosedur yang digunakan masih tidak tepat, menurut peneliti ini dapat pula dipicu oleh rasa malas dan kurang percaya diri untuk melakukan pemeriksaan sendiri.

Dari responden yang memiliki persepsi positif mengenai manfaat SADARI masih ada $(29,0 \%)$ yang memiliki perilaku SADARI tidak baik, Menurut dan berdasarkaan hasil analisa kuesioner terlihat bahwa responden memiliki kemungkinan memiliki SADARI yang tidak baik karena mereka tidak memahami prosedur yang seharusnya dalam melakukan SADARI yang baik, sehingga prodeur dan langkah yang digunakan belum tepat dan menurut peneliti, ini dapat disebabkan oleh adanya hambatanhambatan yang dirasakan oleh responden, misalnya ketakutan responden akan kemungkinkan terburuk dari hasil pemeriksaan.

Bila dibandingkan dengan teori Health Belief Model (HBM), maka hal tersebut bisa dijelaskan bahwa perilaku tindakan preventif seseorang memang dipengaruhi oleh beberapa faktor, antara lain faktor keuntungan dan hambatan dalam melakukan SADARI. Bila variabel keuntungan melakukan SADARI lebih besar daripada hambatannya, maka individu tersebut akan melakukan SADARI sebagai tindakan pencegahan kanker payudara.

\section{KESIMPULAN DAN SARAN}

Berdasarkan hasil penelitian didapatkan bahwa perilaku SADARI di Fakultas keperawatan Universitas Andalas masih kurang baik. Hasil penelitian menunjukkan bahwa dari 76 mahasiswi, terdapat 45 orang atau $59,2 \%$ yang memiiki perilaku SADARI tidak baik dan masih cukup banyak mahasiswi yang memiliki persepsi negatif mengenai manfaat SADARI yaitu 45 orang $(59,2 \%)$. Begitu pula dengan mahasiswi
Pada hasil penelitian ditemukan pula $(44,4 \%)$ responden yang memiliki persepsi positif mengenai hambatan namun perilaku SADARInya masih tidak baik, menurut teori health belief model tindakan akan dipengaruhi oleh hambatan dan manfaat. Jika responden merasa tidak memiliki hambatan, namun ia tidak merasakan manfaat maka ia akan malas dalam mengambil suatu tindakan. Begitu pula sebaliknya. Individu mungkin merasakan manfaat terhadap suatu perilaku tertentu tetapi pada saat yang sama mereka juga mungkin merasakan hambatan. Hasil analisa kuesioner menunjukkan perasaan tabu, malas dan merasa tidak mampu melakukan dengan benar adalah hambatan yang dirasakan oleh responden.

Dari hasil penelitian terdapat persamaan dengan hasil penelitian Norman dan Brain dalam penelitiannya pada wanita dengan riwayat kanker payudara di Wales Inggris, terdapat hubungan signifikan antara perceived barrier (persepsi hambatan) dengan breast self examination. Begitu pula hasil penelitian Desanti (2008) pada wanita berisiko kanker payudara di Semarang, Jawa tengah, terdapat $70,1 \%$ responden yang mempunyai persepsi negatif tentang hambatan perilaku SADARI, serta terdapat hubungan dengan perilaku SADARI dengan $p$ value 0,015 .

yang memiliki persepsi hambatan negatif masih cukup banyak yaitu 40 orang $(52,6 \%)$.

Disarankan bagi pada mahasiswi agar mampu melanjutkan dan lebih meningkatkan perhatian terhadap pendidikan kesehatan reproduksi, khususnya tentang kanker payudara dan tindakan preventif serta promotif yaitu dengan Pemeriksaan Payudara Sendiri (SADARI). Bagi Institusi diharapkan dapat mengembangkan kurikulum dan meningkatkan peran pendidik dalam 
NERS JURNAL KEPERAWATAN Volume 10, No 1,Maret 2014 : 94-101

menyampaikan informasi tentang kanker payudara dan tindakan deteksi dini kanker payudara dengan pemeriksaaan payudara sendiri (SADARI) sehingga mampu meningkatkan pengetahuan dan keterampilan mahasiswi daalam mengaplikasikannya.

\section{DAFTAR PUSTAKA}

Azamris. (2006). Analisis Faktor Risiko Pada Pasien Kanker Payudara di RS M. Djamil Padang. Cermin Dunia Kedokteran ;152:53-6.

Bustan, M. N. (2007). Epidemiolagi Penyakit Tidak Menular. Jakarta: PT Rineka Cipta

Departemen Kesehatan RI, (2007). Buku Acuan Pencegahan Kanker Leher Rahim dan Kanker Payudara. Jakarta; Direktorat Jenderal PP \& PL.

Departemen Kesehatan, (2008). Deteksi Kanker Leher Rahim dan Kanker payudara. Diakses pada tanggal 2 januari 2013 dari: http://www.depkes.go.id

Departemen Kesehatan Republik Indonesia 2008. Laporan Hasil Riset Kesehatan Dasar (RISKESDAS) Nasional 2007. Depkes RI : Jakarta.

Desanti OI. Persepsi Wanita Tentang Kanker Payudara dan Perilakunya dalam

Melakukan Pemeriksaan Payudara Sendiri (SADARI) Studi terhadap Wanita Berisiko Kanker Payudara di Kota Semarang, Jawa Tengah. Perpustakaan
Pusat UGM. Diakses pada tanggal 20 Februari 2013 dari : http://etd.ugm.ac.id. Kearney, A, J, \& Murray, M, (2006). Evidence Against Breast Si of Examination is not Conclusive: What Polymakers and Healt Profesionals Need to know, Journal of Public Healt Policy, 27, 3 Proquest Med cal Library Pg 282.

Norman P dan Brain K. Health Belief Model And Breast Self-Examination : An Application of The Health Belief Model to The Prediction of Breast Self Examination in A National Sample of Women with A Family History of Breast Cancer. University of Wales College of Medicine UK

Notoatmodjo, S. (2003). Pendidikan dan Perilaku Kesehatan. Jakarta: PT Rineka Cipta. (2007). Promosi Kesehatan

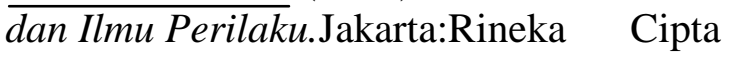
(2005). Metodologi Penelitian Kesehatan. Jakarta : Rineka Cipta 